\title{
ESSENCE OF SELF-EDUCATION COMPETENCE IN PEDAGOGY
}

\author{
Santa Striguna \\ Liepaja University, Latvia
}

\begin{abstract}
Promoting the challenges of future education system in the context of public education, the term of competence and self-education competence is set in the spotlight of the article. Analyzing the comprehension of the essence of the diverse competence, the author systematizes the qualities which characterize the competence. The term of self-education and its structure based on the analysis of theoretical resources is characterized, the criteria are conveyed which characterize the future teachers' self-education process. The goal of the article: on the basis of the theoretical resource studies systematize the diverse comprehension of the concept competence and characterize the structure and components of the students, future teachers' self-education competence.
\end{abstract}

Keywords: competence, self-education, self-education competence, structure.

\section{Introduction}

The $21^{\text {st }}$ century is the time, when not only in Latvia, but also in the whole world, the change of educational institutions' roles and functions takes placeteachers have to work in a multicultural environment, students with special needs are integrated into schools, the significance of information and communication technologies in the study process increases fast, parents' involvement in the school and study process increases. The above mentioned set of circumstances reveals to teachers the necessity for more and more new competences, since education is a purposeful development process and also the outcome of the process. Education is a life-long process and due to it the personality's level of education increases. An educated person's skills are a developed ability to generate the personal judgements and behavioural strategies, analyse and assess their life activities, improve constantly the personal experience, develop self-regulation and plan self-development. The base of the above mentioned skills is the self-education competence.

Nowadays in the labour market a situation has been created which confirms that only competent, self-organized and full of initiative specialists, able to selfrealize both in a professional and personal area become competitive and more demanded specialists. This means that self-education becomes an active element of different social groups' dominant lifestyle, which promotes the change of individuals' roles in the public social structure, activating the significance of self-education process, for self-education is the factor and indicator of the personality and society's development. Self-education is determined by the interaction of the individual and society's needs. Self-education characterizes 
the completeness of activities, and at the same time it is also the source of selfdevelopment. Self-education is the way of the subject's self-realization and selfdevelopment which greatly determines their real and potential opportunities in the system of social connections, relationships and interaction. Therefore the goal of self-education is the subject's self-development, self-realization and selfimplementation not only in the personal dimension, but also in wide social context.

The contradiction between the breadth of knowledge and human being's abilities to acquire them is one of the main problems in the $21^{\text {st }}$ century. The life-long learning support learn to be means develop more own personality and be able to work more and more independently. Therefore the development of self-education abilities is considered as one of the adults' self-education guidelines. Self-education issues are especially topical and significant in the pedagogic reality. The future teachers' training in the context of future challenges is a controversial process. The length of the future teachers' study programme is 4-5 years. However, no matter how good these programmes are, they cannot prepare the new specialists for all challenges in their pedagogic work.

The OECD research (2013) promotes the necessity to extend the border of teachers' further education, since "only it can provide high teaching standards".

Also "Development of Competences" is one of the directions of National Development Plan of Latvia, in which the topicality of life-long learning is emphasized - "Competences have to be developed throughout one's lifetime, as we cannot predict the future needs (National Development Plan of Latvia 20142020).

The educator A. Spona also mentions the topicality of the problem in the education field saying that mostly scientific researches dominate in pedagogy, as well as analysis of self-experience, which is directed towards the teachers' personality and the quality of its pedagogic activity, but still less attention is paid to the human qualities of higher educational establishments academic staff and their influence on students' personality and professional development (Špona, 2014).

Goal of the article: on the basis of the theoretical resource studies systematize the diverse comprehension of the concept competence and characterize the structure and components of the students, future teachers' selfeducation competence.

Research methods: qualitative research methods are used in the studies of the theoretical literature, normative and other documents: analysis and synthesis, the logically constructive method in order to work out conclusions and generalizations. 


\section{Comprehension of Competence Concept}

Students, when acquiring an individual experience, form their learning, education and interaction culture in a particular sociocultural environment (Виготский, 1984).

First of all, it is necessary to specify the comprehension of the concept competence which has been developed since the 20 s of the previous century. When talking about the human being's possibilities, about the professional and human requirements, which are imposed on a modern human being, the concept "abilities" is often replaced with the concept "competences." The explanation of it can be found in the social and cultural progress which sets very high requirements to separate individuals in relation to the skills to assess, analyse and act in new and unfamiliar situations. The competence "becomes an expression of such a skill which gives a human being an opportunity to manage and act in the social and cultural diversity that can be obtained through learning (Eichorst A., 1998). Thus, in the contemporary perspective the human being has to be professionally qualified in a broader sense. The knowledge in own professional area only is not sufficient any longer, a human being has to be able to implement the knowledge according to the requirements of a particular situation, the skill to improve one's knowledge in the fast changing world has to be acquired.

In scientific literature of Latvia the dominant comprehension of the concept competence is being promoted on the basis of the knowledge, skills, attitudes and responsibility's wholeness. The synonym of the competence concept in Latvian according to the academic Rauvarger's studies could be considered as the term expertise (lietpratība-in latvian) (Rauhvargers, 2004). Competence is the wholeness of knowledge, skills and attitudes which qualifies for a certain type or level of task achievements. Each individual's activity is always characterized by a certain level of competence or expertise which is expressed in the following kinds of competences:

- professional competence;

- $\quad$ social competence;

- $\quad$ individual competence (Valbis, 2005)

In its turn, F.Perrenoud's competence according to its implementation and expression specification is divided into several groups:

- disciplinary competence which includes planning, analysis, synthesis, methodology;

- professional competence which includes professional communication, activity in a multicultural environment, development of abilities;

- institutional competence which includes innovative activity, implementation of innovations into practice, ability to work autonomously and in a group, transformation of interdisciplinary knowledge (Perrenoud, 2004). 


\section{SOCIETY. INTEGRATION. EDUCATION. Volume I}

The diversity of the competence comprehension concept is conveyed in the concept interpretation:

- $\quad$ competence as knowledge, abilities (Beliickis, 1998);

- competence as skills (Maatsch, 1990);

- competence as experience (Леонтьев, 1977; Špona, 2001; Koķe, 1999);

- $\quad$ competence as readiness to act (Stabiňš, 1998);

- competence as a result- on the level of the human being's activity (expressed in a particular situation (Chomsky, 1965);

- competence as a process (potential of abilities and opportunities for activity) and as an outcome (quality and experience of an activity) (Tillıa, 2005).

The competence can be formed and expressed only in a close communion with the understanding of the personality's values, i.e., in the circumstances when a person is personally interested in the particular activity (Равен Дж., 1999, 67).

Competence can be looked upon also as an ability to use and develop the obtained experience efficiently: "a unity of complex knowledge, skills and attitudes which is used in action, achieving the result." Knowledge is understood here as the facts, principles and theory of the activity area. Skills are understood as the obtained capacity with the help of learning in order to carry out an activity, using the knowledge (Osborne, 2010).

Competence from the potential possibility changes into the real abilities only through an action. The idea of the activity approach helps to transform the analysis "from a descriptive finding level to a detailed conceptualization level" (Леонтьев, 1977, 38).

The physical, mental and emotional capacity is understood with attitudes in order to implement the activity. The academic A. Špona considers that the base of the human being's competence is the creative self-experience which is formed in the "problematic research study process when a human being is able to use the personally significant knowledge, skills and attitudes obtained through life activities in diverse life situations" (Špona, 2014).

Formation of the professional competence in professional work can be analysed on the basis of the contextual model of the activity approach in the pedagogic work used by the researcher. The researcher mentions that this model gives a possibility to find regularities where the lecturer's goals and students' motives have to comply with each other and have to be united, i.e., the activity content of the teaching staff has to comply with the adult's types of activity, learners' level of development (life experience, level of skills, etc.).

According to J.Stasane's opinion (Stašāne, 2007) self-education in relation to the activity process is:

an adapting type of activity which is based on adaptation to the necessary social conditions; 
- a self-realization type of activity whose goal is self-education, subject's self-development.

Competence can be looked upon as the indicator of the quality level as it is offered by the researcherI. Jurgena (2002): "The teacher's theoretical knowledge and professional skills in their development through the experience development can be marked as the teacher's professional quality, but the teacher's competence is the expression of quality". In its turn, the lecturer, I.Tilla emphasizes that "competence as a result is expressed on a quality level of a particular situational activity" (Tillla, 2005).

In the professional competence formation process the future specialist's professional development obtains a special topicality already during their studies. The transformation of skills in the professional activity competences is possible only in such a study process where the students themselves are active promoters and participants of their development. Therefore the study process is connected with four significant areas of competence formation. In the future teachers' education they are:

- values orientation,

- $\quad$ social and pedagogic reality,

- comprehension of the new professionalism,

- personal responsibility, interaction and participation (Līdaka, 2007; Maslo, 2006; Samuseviča, 2013; Žogla, 2001)

The quality of the future teachers' self-education competence is provided by the close connection and promotion of the professional development areas in the professional activity acquisition during the study process.

\section{Essence and Structure of Self-education Competence}

Nowadays due to the social transformations the approach of competences is set as the priority of the education system, whose implementation is topical in the pedagogic process. As V.S.Meskov (B.С.Меськов, 2006) and Y.G. Tatur (Ю.Г.Татур, 2006) emphasize, the approach of competences offer the education outcomes not only the concept knowledge- in the skills-abilities development context, but as the future teacher's readiness for the professional activity (and the level of this readiness), to implement the professional activity in its diverse and complex synthesis.

The educator L.B.Sokolova (2013), analysing the modern approaches of the professional education in the assessment of education outcomes, using the approach of competences, emphasizes the significance and usefulness of the concept self-education competence. According to the experts' opinions of the international organizations (UNESCO, the World Bank) in order to become a competent expert in a particular area, involving a self-educating activity, it is necessary to acquire the basic/central competences. To be competent in selfeducating activity, according to I.A.Zimnyaya's (2003) opinion, it means "to be 
able to mobilize the knowledge, skills and experience." However, the skills to transform the knowledge, skills and abilities in certain situations also have got an essential significance. I.S.Zaire-Beck (2000) explains this approach in a greater detail, emphasising the self-education competence as the leading characteristics of an educator- researcher's personality.

In the researches, where the English psychologist J.Raven touches the competence issue, it is emphasized that competence is a specific ability which is necessary for an efficient implementation of the particular activity in certain subjects' area, including highly specialized knowledge of a particular kind subject's skills, ways of thinking and sense in action. In the researches J.Raven separates intentionally the concept higher competence, which notwithstanding its particular area of existence speaks about the:

- existence of a high level initiative in a person,

- ability to organize others for the goal achievement,

- $\quad$ skill to assess and analyse the social consequences of the activities (Raven, 1990).

L.Sokolova (2013) and G.N.Podcalimova (Подчалимова, 2012) emphasize the attraction of self-education competence to the higher level competences, pointing out that "self-education competence should be considered as the subject's comprehensive and professional education," which includes in itself the following structural components with corresponding criteria (see Table 1).

Table 1. Components and criteria of self-education competence (SC)

(Подчалимова, 2012; Sokolova,2013)

\begin{tabular}{|l|l|}
\hline Components & Criteria \\
\hline Motivation - values & $\begin{array}{l}\text { professionally - personal awareness and realization of self- } \\
\text { development } \\
\text { striving, (inclination) to the personal and professional } \\
\text { development }\end{array}$ \\
\hline Cognitive & - stable motivation of a qualitative SC performance \\
\hline Operationally-active & - personisition level of SC knowledge and skills \\
& - acquisition of SC formation methods \\
\hline Reflections & - adequate assessment of SC and self-education activity (SA) \\
& - need for the professional reflection of SA \\
\hline
\end{tabular}

Taking into account the fact that the self-education ability is formed in action, the authors L.Sokolova (2013) and G.Podcalimova (Подчалимова, 2012) distinguish the concept self-education competence that is described as a personality's quality which is characterized by a systematic, independent and organized cognitive activity that is directed towards the continuation of personal 
education in the general-culture professional aspect. Apart from that the selfeducation competence is based on the experience of the self-education activity and the teacher's strive to extend their pedagogical professional development and action potential.

In the teaching practice the self-education competence is not only the wholeness of specified abilities and skills, but it is also the experience of the professional action, it is influenced by the teacher's personality. Therefore within the work of teacher training higher education establishments it is necessary to work out conceptions and approaches based on the theory which determine how to improve every future teacher's individual learning abilities and skills that are necessary for the development of the self-education competence, and also provide possibilities and circumstances for the acquisition of this work experience.

The development of teacher's professional competence is the basic task of competence approach implementation in higher education (Skorobogatova, 2011).

The teacher's personality and experience, and the wholeness of abilities and skills greatly characterize the self-education competence in pedagogic activities. The quality of the professional activity in pedagogy branch is closely connected with the development of the self-education competence, which, in its turn, reveals the necessity within the work of teacher training higher education establishments to be aware, plan and implement the study process which forms the future teacher's abilities and skills that are necessary for the development of the self-education competence, as well as provide circumstances for the acquisition of this work experience.

The self-education competences are characterized by consecutive systemforming activities, the way as they are determined by the formation of other key competences, for in the study work the self-education competence is not only the goal, but also a tool for an efficient personality's development in the education process. The self-education competence can be described as an integrative quality of the personality's activity, which is characterized by the personality's ability according to a systematic, independently organized cognitive action, directed towards the further education in general-culture and professional aspects, and it is formed, organized and controlled by the cognitive action subject itself.

The teacher's self-education is a purposeful, independent daily professional development action, acquisition of the psychologically pedagogic and methodological knowledge, constant analysis and reflection of pedagogic problems, search for innovative solutions whose goal is a conscious, selfconstructed and self-managed development in the personal, professional and social context, implementing the provision of pupils' more efficient development. 


\section{Conclusions}

Comprehension of the competence approach is characterized differently- in compliance with the specific facets and nuances of the professional activity, but practically all researchers come to a common consent that in the specialists' training process the orientation towards the personality and professional competence plays the major role.

The self-education ability is one of the essential parts of the professional competence, for the self-education ability is included in the requirements of education outcomes. In the modern society self-education is one of the basic preconditions of the professional activity which is set for education and simultaneously it is an influential factor of the professional development of the teacher's personality.

A successful teacher-practitioner's self-affirmation in the professional activity and a wholesome self-realization greatly is determined by the fact how during the study process the future teacher has been directed towards their development searches and confidence that the professional mastery depends on the personal self-development and self-improvement.

The theoretical analysis confirms that the structure of the self-education competence includes in itself several significant components:

- integrative personal characteristics which provide an emotionallyevaluative attitude towards the self-development and self-education with a knowledge system about the planning and implementation of self-education activity;

- subjective personal experience, productive experience of selfeducation problem solving, as well as development and implementation experience of self-education activity;

- readiness for self-education, organization of personal self-education techniques.

Therefore, one of the main tasks in the future teachers' training is the students' preparation for a continuous self-education in their pedagogic work, emphasizing the following components in the study process: motivation values, cognitive, operationally - active, reflections.

This paper has been supported by the European Social Fund within the Project „Support for

Doctoral Studies at Liepaja University" (Nr.2009/0127/1DP/1.1.2.1.2./09/IPIA/VIAA/018)

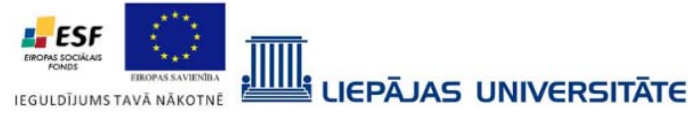




\section{References}

Beḷickis, I. (1998). Izglītības alternalīvās teorijas. Rīga: RaKa.

Chomsky, N. (1965). Aspects of the theory of syntax. Cambridge, Maas.

Eichorst, A. (1998). Selbststtatigkeit im Unterricht, Munchen.

Jurgena, I. (2002). Topošo skolotāju profesionālās kompetences veidošanās iespējas studiju procesā. Rīga: RPIVA.

Koḳe, T. (1999). Pieaugušo izglìtības attīstības raksturīgākās iezīmes. Rīga: Mācību apgāds.

Latvijas Nacionālais attīstības plāns 2014-2020. Retrieved from http://www.varam.gov.lv/ lat/pol/ppd/ilgtsp_att/?doc $=13858$

Līdaka, A. (2007). Ieteikumi vērtībizglītības realizācijai I. Liepāja: LiePA.

Maatsch J.L. (1990). Linking Competence to Assessment tests. San Francisco p.35-48

Maslo I. (2006). Nozināšanām uz kompetentu darbību. Rīga: LU Akadēmiskais apgāds.

OECD (2013), OECD Skills Outlook 2013: First Results from the Survey of Adult Skills, OECD Publishing. http://dx.doi.org/10.1787/9789264204256-en

Osborne, M. (2010). Key Competences for Adult Learning Professional. Retrieved from http://www.realrpl.eu/media/realrpl/documents/Key\%20Competences

Perrenoud, P. (2004). L'universite entre transmission de savoirs et developpement de competences. Geneve. Universite de Geneve.

Raven, J. (1990). The Most Important Problem in Education is to Come to Terms with Values. New York, Trillium Press.

Rauhvargers, A. (2004). Boloņas procesa un ES kvalifikāciju ietvarstruktūras - kopējais un atškirīgais. Retrieved from: http:// www.apa.lv

Samuseviča, A. (2013). Pedagoǵiskās kompetences aspekti augstākajā izglītībā. LU raksti Pedagogija un skolotāju izglìtība. p.56.-64.

Sokolova, L. (2013). Self-educational Competence of Young Researchers of Pedagogical Problems: Methodological Aspect. Middle-East Journal of Scientific Research 15 (3). p.339-343.

Stabiņš, J. (1998). Audzēkņu gatavības veidošanās dzīvesdarbībai komercskolas pedagogiskajā procesā. The doctoral thesis in pedagogy science. Rìga: LU PPI.

Stašāne, J. (2005). Personības pašrealizācijas problēma pieaugušo izglītībā. Zinātnisko rakstu krājums. Pedagogija: teorija un prakse III 3.daḷa. Liepāja: LiepA. 221.-231.

Špona, A. (2001). Audzināšanas teorija un prakse. Rīga: RaKa.

Špona, A. (2014). Jauni principi audzināšanā. Teorija un prakse mūsdienu sabiedrības izglìtībā. VII Starptautiskās zinātniskās konferences rakstu krājums. Rīga: RPIVA, p.188-193.

Tatur, Y.G. (2004). Competency-based approach in the describing the results and design of higher education standards. Proceedings of the second meeting of the methodological seminar. Moscow.

Tiḷıla,I. (2005). Sociālkultūras mācīšanās organizācijas sistēma. Rīga: RaKa.

Valbis, J. (2005). Skolēna personības attīstība - izglītības virsuzdevums. Rīga: Zvaigzne $\mathrm{ABC}$.

Zaire-Beck, E.S., Solyannikov Y.V. (2000). Technology of teaching the research activity as a factor in high-quality training of researchers at the Pedagogical University. In Preparation of specialist in the field of education: research and organizational problems of training the highly qualified personnel: a collective monograph. St.Petersburg: Harzen State Pedagogical University, Issue IX, pp.96-114.

Zimnyaya, I.A. (2003). Key competences - a new paradigm of education result. Higher education today. 5: 34 - 42.

Žogla, I. (2001). Skolas pedagogiija. Rīga: LU. 


\section{SOCIETY. INTEGRATION. EDUCATION. Volume I}

Виготский Л.С. (1984). Речь и мышление. Москва: Просвещение.

Леонтьев А.Н. (1977). Деятельность. Сознание. Личность. Москва: Политиздат.

Подчалимова Г.Н. (2012). Развитие самообразовательной компетентности студентов в процессе проектной деятельности. Ученыезаписки: электронный научный журнал Курского государственного университета. No.4 (24) T.1

Равен Д. (1999). Компетентность в современном обществе. Москва: Когито-Центр.

Скоробогатова Т.С. (2011). Развитие самообразовательной компетентности у будущего учителя информатики. Педагогическое образованиев России. 2011. No. 4 p.206.209. 